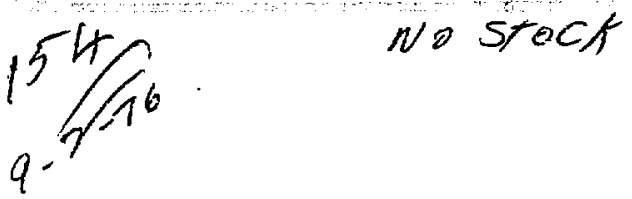

\title{
TECHNICON AUTOANALYZERS: FUNCTIONAL DESCRIPTION
}

Rtehard W. Crawford

George W. Barton, Jr.

April 1, 1976

Prepared for U.S. Energy Research \& Development

Administration under contract No. $W-7405-E n g-48$

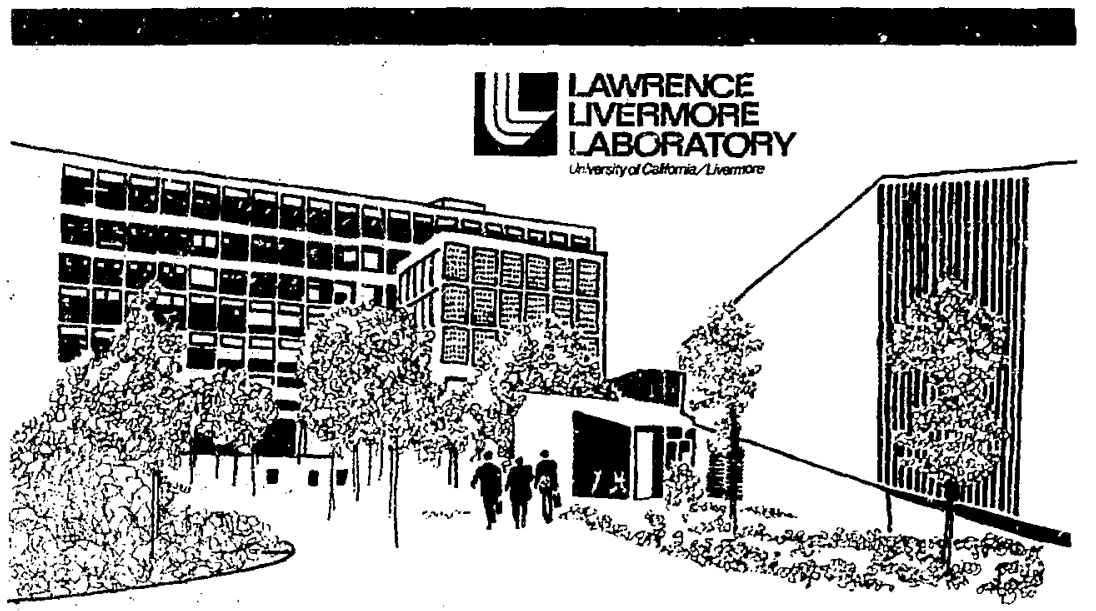




\section{NOTICE}

"Thle report we propered ce en ecoount of worl poesand by the Unted Stefes Gownmant. Noithe the Ualied Stated nor the Unired Strtes Emety Rewere a Devilopinet Adpinitiration.

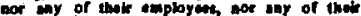
contricion, subcontractors, of that employest mikes any wanty, expren of implied. of coumes any lat isbilty of respontibility for the eccuncy, complateses of mefulnets of any

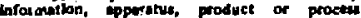

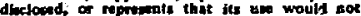
Iniflese privately-omed rights."

Printed in the United States of Americe Aviluble from

National Technical Informathy Service

U.S. Department of Commerce 5285 Port Royal Road

Springfield, ' VA 22161

Price: Printed Cogy 5 ; Microfiche $\$ 2.25$

$\therefore$

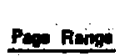

Domertic

\begin{tabular}{c} 
Price \\
\hline $\begin{array}{c}3.50 \\
4.00 \\
4.50\end{array}$
\end{tabular}

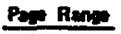

Domeric

$001-025$

4.50

$326-350$

026-050

5.00

$351-375$

10.00

051-075

5.25

$376-400$

10.50

076-100.

401-425

10.75

101-125

5.50

$426-450$

11.00

126-150

6.00

451-475

11.75

151-175

7.50

476-500

12.00

176-200

7.75

$501-525$

12.50

201-225

8.00

$526-550$

12.75

$226-250$

9.00

551-575

13.00

251-275

9.25

$576-600$

13.50

276-300

9.75

60J-up

13.75

$301-325$

Afa 32.50 for ench additional 100 page bacrement from 601 to 1,000 pases: add: Y 450 for each additionis 100 puse incremest over 1,000 pates. 


\title{
近 \\ LAMTENCE LIVERMORE LABORATCRY \\ Liaverstyol Cationa Luermore, Caboma 94550
}

LCKL -52046

\section{TECHNICON AUTOANALYZERS: FUNCTIONAL WIISCRIPTION}

\author{
Richard k. Cratiord \\ George $W$. Barton, Ir. \\ MS. dace: Afril 1,1970
}

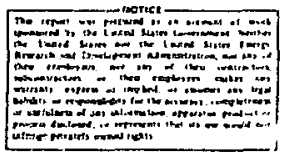




\section{Conients}

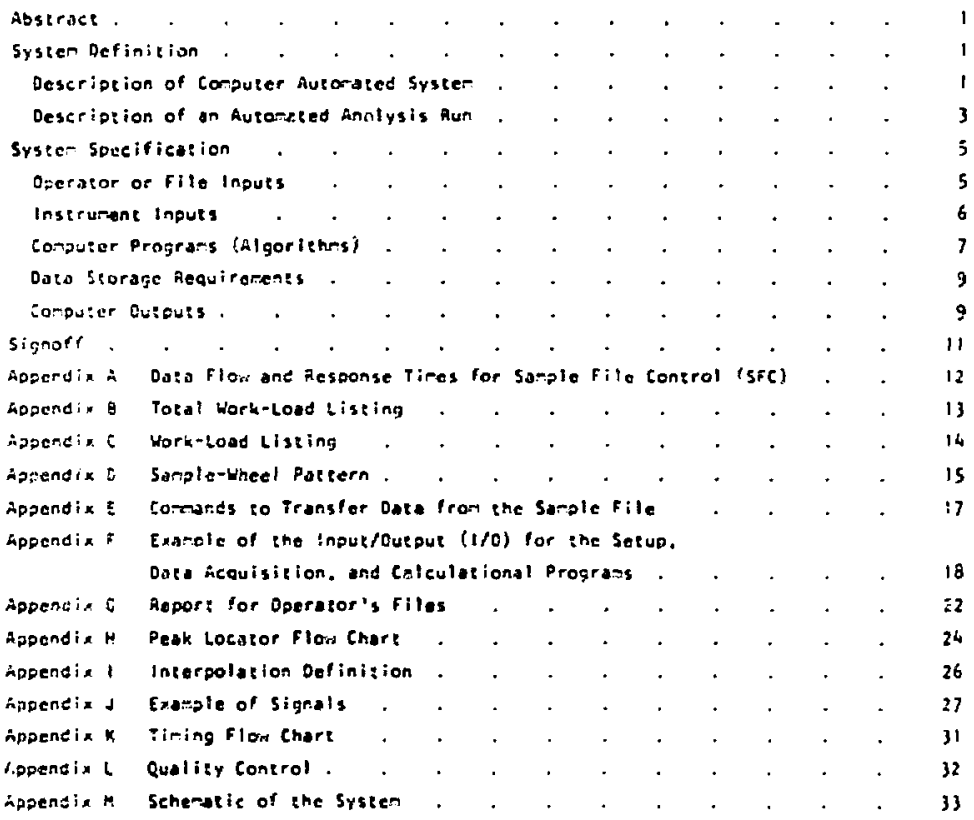




\title{
TECHNICON AUTOANALYZERS: \\ FUNCTIONAL DESCRIPTION
}

\begin{abstract}
This docune of describes and specifies 2 Computer outputs during and th the end of comnuter outomtion system for the Technicon ausofinalyzars (1, 1), and CSM-6 colorireter). Operator inpuls and interaction during the analysis run ore described. the run are described and illustraced. The computer colculates concentrations, monitors qual lis control, and prepares reports.
\end{abstract}

\section{System Definition}

DESCPIPTIOH OF COMPUTEA AUTONATED SYSTEM

\section{Ineroducsion}

Provisions will be made for toking data from five channels of Technicon Autadnelyz. of 1. four channels of Technicon AutoAnalyzor 11, sne six Shonge!s of.Techy icon.AugoGnalyzer c5n:-6 colorimeters. 0 The detector output signal of each colorimeter will be condit toned and interfaced for computer roading. Compuler analysis algorithas lorogrampl will be provided for each ondysis train and will sutoestically tire the signol readings, calculate concentrations, and correlake results with sample identificelions.

The computer atgorithms will also contein - varloty of subroutines for boolikecping. dato processing. ediling, and refort writing.

\footnotetext{
Thems that are new and not pore of the existing system re indlcated by a bar in the margin. sometimes supplemented by a dashed underline if roqulrad for precisa Indication.
}

They will be writeten in a conversationol node so that the operator may interact with the computer by a series of questions, answers. and commonds. Algorithms to keep track of sample and ezlibration daba, to make simple quality checks, and to.transfer date. zo_and fron_the_samele_file_cenerol Ier will he used te minimize inputs and manlpuIakin of numbers by the operator.

\section{Somple file cuntreiler}

The futofindlyzer systens will be linkad with the sanple fite conzroller so that the operator can (1) cxamine his work lood by getting - listing of all samples requiring andlyses for any consticuent by the Auloknalyzers: (2) call for o listing of Aucokndyzer sarples by constituent; (3) cransfer a group of sample identification numbers to the Autodinalyzer analysis algoeithms for a computerlzed run; (4) call for - position man for the 40-position sampler; (5) transfer the resules of a computerized run to the sample file cortsoller; (6) quiz 
the file by sample number to check a pariicular sample, change a value, or input a value from a manual ren or special situation; (7) compare two or more states of the same element (e.g.. total Kjeldahi nitrogen and ammonia) while conducting a run: (8) list the concentration of one state of an element (if available) on the work-load listing of another listing (e.g.. inorganic phosphorus on the total phosphorus listing).

A functional schematic of the file is shown in Appendix A. Examples of work load listings are shown in Appendices $B$ and $C$. The sample whel setup pattern for the operator in Appendix 0 is prodiced as shown in Appendices $E$ and $F$.

\section{Computer Reports to the Operator}

The concentration of each sample will be calculated and returned to the operator as the analysis proceeds. It will also be stored for teransfer_to che data_file. and for generating a temporary report. At the end if a computerized run, the operator can obtain a report of all analyses in the ruin a format suitable fer his files, transfer.the_data_to.the datg_f!!e, and clear his prograis on command. Final results for sediments_ul!!_be_calculated when_samele dry_weights have been_entered. Appendix G shows an example of the operator's report.

\section{Data Acquisition}

The system will ubtain a digltal computer readout of the colorimeter outputs as the AutoAnalyzers aspirate standards, samwles, and ulanks from the automatic sampler modules. The computer will look for absorption peaks above background at appropriate intervals as samples pass shrough the colorimeters. The peak reading will be associ- ated with the particular sample being run and will he used to calculate the concentration of the cunstituent being determined. A sehematic of the peak-locator routine is given in Appendix $\mathrm{H}$.

The sample number and concentration will be reported as the analysis proceeds.

\section{Calculations}

Calculations of concentrations will be done by first- or second-degree leastsquares ficting of the standard curve or by sample interpolation as desirad by the operator. A schematic of the interpolation routine is shown in Appendix 1.

Baseline corrections will be made by calculating the slope between instrument blanks and then correcting each sample in between the blanks. The amount of correction will depend on the time elapsed since the last blank and the slope of the baseline.

Civlculation of tolal phosphorus and total Kjeldahl nitrogen from sediment sumples requires both the wet weight and percent dry weight in order to calculate the final concentration in milligrams per gratn. If either of these values is not available at the time of analysis, the concentration will be reported in milligrams per liter during the run and flagged as temporary.

Phosphorus results can be calculated eleher as $\mathrm{PO}_{4}$ or $\mathrm{P}$ at the operator's request.

\section{Sampling}

Six Technicon AutoAnalyzer samplers will be used (one.CSH-6, three TAA-1, and two TAA-1 I samplers). These are 40-position samplers and are internally $t i$ med with a motor and cam. The number of samples per hour can be set by the aperator. This rate 
varies from 20 to 60 samples per hour, depending an the type of determination.

In the case of the CSM-6 samples, one to six different analyses are run simultaneously from the same sampler. Examples of this are analyses for ammonia, nitrite, phenol, and silica.

\section{Discrete samples are aspirated for 1} to ? minutes. Ten to thirty minutes are required for the sampie to reach the colorimeter detector through the AutoAnalyzer chemical pracessing systems. Thus there will be a time delay before the first sample solution arrives at the detector; then sample solutions will pass through the detector flow cell at the sampling rate unt il ali samples in the run have becn processed. The sulutions flow through the flow cell continuausliz, and the constituent concensration builds up to a peak valuc as the middle porticn of the sample stream passes througt: the fluw cell. The TAA-1 and $\$ \$ M=6$ samplers give sharp peaks; ?he TAA-II sampler gives a plateau. The signal will be read at the peak or on the plateau. Examples of the signal are shown in Appendix $\mathrm{J}$.

DESCRIPTIOH OF AN AUTOMATED ARALYSI'; RUN

A description of a typical actomated analysis run is given below. See the foi:lowing appendices for more detalls of the system operation:

Appendix of for an example of the samplewheel pattern output.

Appendix $F$ for an examale of the input and output required to inltiate and complete a run.

Appendix $K$ for a flow thagram of the AutoAnalyzer timing.
Appendix $L$ for a flow diagram of the quality-control procedure.

Appendix $M$ for a functional schematic of the entire system.

The operator will select a curntableloading pattern and load standards, blanks, samples, and quality-contral solutions according to the pattern selected. The pattern will start with three setup standards, follcied by two blanks and the standards for the calibration curve. It then follows the repeating sequence of samples, blanks, and quality-contru: solucions that was specif ied at the beginning of the run.

The concentrations of the calibration standards can be entered by the operator at the beginning of the run, or they can be stored if the same ones are aiways used. The computer will corralate the value of each sample with the sample number. The operator wil! have the option of logding the sameles _in_she_order_read from _a comeuterzeregared_samele_list. This_ayoids having to enter samele numbers. Alternatively, he can load samples in any order he chooses, but then he must manually enter the sample numbers. The çomputer_can_also be instrucjed_to_randgn!y_select_samele numbers to el iminare bias.

The operator should be able to enter mulkiple dilutions of the same sample into the sample-wheel patcern. The computer shuuld select the highest on-scale peak for each analyte.

Hore than one sample-wheel pattern for an analyte may be created and stored in the computer system. This is particularly useful for analyses (e.g., total phosphorus) that require autoclaving or other extended pretreatment. Thus the pattern is created, 
the samples and standards put in correct order and pretreated. The pattern is stored and a prevlously treated ser of samples is run using the previously stored pattern.

An aption_wi!! be avsilable co_autonatically create sno di fereng samplezhee! pattgerns at the same time for such analytes as_the_tota!_kleidah!_nitrogen: ons_for normal water samples and the other for sediment sameles. An aption is also svailable to run ail sumples as duplicates for such applications as inoryanic and total phosphorus andysqs.

Occasionally so many samples are entered into a sample-wheel pistern that they can" not be finished in one day. The program will auzomatlcally insert a paztern of settp standards, blanks, and calibrotion standards at the operatur-5elected point so that the remairitig samples can be run wighout being reenterisd on the following dar.

The baseline will be tstablished before tre calibration stindards and will be updated on the basis of blanks in the sumple sequence. The raw digital readings of the baseline and calibrition standards vill be returned as they are taken, for operator inspection, and stored for calcilating the concentration of samples. The calibration data will be processed according to the type of calculation desired ffirst- or second-degree lesst-square; fitting, or interpolation). The factors to be tised to calculate concentrations will be rerurned when the last standard solution has becn read.

The operator will examine the calibration data. If he is satisfied with it, the run will continue; if he is not satisfied with the data, he can stop the run and restart.
One pass will be rade un all solutions, $a$ valus being returned fur each. This ini:ial concentratiar will be an approximation based on the previous inseruent blank read. Af ter the next instrument blank is read, all samples betwee! the two tlanks will be corroced for any slope in the bachground The corrected cuncentrations moy tmets budizElayed:_A_zes_standardwill ge_used_as the first run of each trdi after the oirst gras. Ihis wi!! be uste by the conguger lu recttablish timitg when . sackle.trays ar: shange. He.pejh-height inforougion is availatle from_this stondard.

Quatity-control churt inforstation will be calculated and stored far spikes, check standards, and duplicales, Either the Cusum, Shewhare ${ }^{2}$, or Indusiriol; methoo can be selected. As each cuality-control standard is run, it will be checked aydins: the appropriate linits; if the standard is out of limits, a warning will be disclayer and a buzzer sounded. The

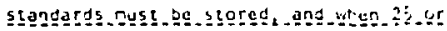

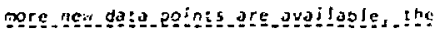
opcralor computer wil! ereatenew chart linits fros thescosgat.

An approximate concentration and on apreopriate dilution factor will the calculaced for off-scale samples: a buzzer will sound to alert the operator. The computer

Anon., Laboratory Qualley Concrol Munual. Federal Water Pollution Control Administratlon, Robert S. Kerr Hater Research Center (1969).

2w. A. Shewhart, Economic control of Qualley of Manufactured Produres (193!).

3E. G. Robles, Jr., U.S. Air Force Environmental Health Laboratory. McClellan Air force E_sé, Sacramento, Calif., personal comsiunication. 
will store the dilution factor and identification number of the off-scale samples and louk for them in the sequence reported, at the end of the run, autconalically. The computer will also be able to give a listing of all off-scale samples at predetermined points. The operator will prepare dilutions according to the dilution factors suggested and load :hem in the order found, starting in the ntxt sambler posi- tion. The concentration of the diluted solution, the difution factor, and the concentration of the original sample will be returned.

The operator can obtain a recort suitable for his files and_transfer.the daț E. ihe data filles_ypon completion of the run. The data used to crease the appropriate control charts can also he listad for storage.

\section{System Specification}

\section{OPEAATOR OR FILE INPUTS}

The carpuicr mus: have certain informatior in arter to derform its lasks such at data logging, salculations, or report writint. There are tradeoffs between permanently storing the information or enteriny is frori a heyboard as each run is see af. The first i, faster. the second more flexible. All of the infermation that the compuler requires is detailed here without specifying which items will be permanently stored and which must be entered by the operator: Appendix $F$ contains our suggested trade-off. Since the programing is in 8.451C, a high-level language, it is casy to make changes as needed.

\section{Interaction with the Sample file control- ler (SFC)}

1. The constituent ( 5 ) for which the $f i$ ile is to be searched to get a work-load listing.

2. The constituent, if any, whose concentration is to be listed on the workload listing.

3. The constituent for which identifi- cation numbers are to be transferred from the file to an analysis algorienm.

4. The rigst and last identification number :o be : ransferred from the tile to the analysis algorlthm.

5. A comand to transfer the results of a run to the data file.

\section{Timing information}

1. Three large peaks as the first three samples in thic first wheel.

2. One large peak at the start of ail sutsequent whee is.

3. The number of samples ler hour as determined by the sampler cam.

\section{Standards Information}

1. The nuriber of standards in a calibracion set.

2. The concentration of each standard.

3. The units of concentration for each constituent to be determinec.

4. The location of each standard in the sampler.

Quality-Control Information

1. The number of quality control solutions in a run. 
2. The concentration of each qualitycontrol solution.

3. The location of each quality-control soivtiors in the sampler.

4. Quality-assurance criteria for signaling the operator.

Sampie information

1. The number of samples in each run.

2. The identification number of each sample.

3. The location of each sample in the sampler.

4. It z dilution factor for each diluted sample on the initial run.

5. The number of dilutions of the same sample and the dilution factor of each.

\section{Hode of Ealculacing Concentrations}

i. By first- or second-degree leastsquares fitting of the standards data.

2. By simple interpolation between the two nearest standards. A scheratic of the interpolator routine is show in Appendix 1 .

3. Concentration as percent dry weight. The appropriate equation is used, taking into account the wet weight of the sample, the volume, and the percent dry weight of the sediment.

Interactions During the Course of a Run

1. A command te halt a run in the event of out-of-control conditions or equipment failure.

2. A command to restart the run in the event of an incerruption. The information needed in this command includes the following:

a. Sampler position. b. Identification of the starting sanple. stancise or blank.

3. A command to list ali samoles that must be rearalyzed and the reuvis dil.-bions, if necessary.

Data fur Operator's File at the end of a Run

1. Date.

2. Operator.

3. Instrument conditions.

4 Standards source.

5. Tha mode of calculation and r.. $\mathrm{n}$ stants used.

6. The taits of concentration.

7. Comand to generate a ruport lan example of a report is shown in Appendix G).

\section{INSTRUMEI:T INPUTS}

Only one input to the computer fres each Technicon Rurofinalyzer is needed: the output of the photodinde in the colorimeter. The dynamic range of the signal is 10.000 .

Signal Characteristics--AutoAnalazer 11

The source of the signal is telonetry output. Pin 4 is the 'jnal, pin $z$ is the ground, and pin 2 is the guard. Pin 1 is not used.

\section{Signal Characteristics--AutoAnalyzer I}

The source of the signal is a retransmit ting slidewire installed on the recorder. The 5 ignal is 0 to 10,000 ohms full scale.

\section{Sigrial Characteristics--CSM-6}

The signal is $5 \vee$ fu!! scale. Must be able to detect $500 \mu v$. Noise is typically 0.5 -msec, I-V spikes. 
The signal source is teleretry output with jGob-onm ourput impedance. Cannceticns are to terminal board (TE; I. Common is on fin 7. Channcls I ehrough 6 are on pins 1 throuth 6 , respectively.

Anulog filtering can be contolled from C. I to I Hz bafore copouter input.

bastini; conercls are needea for signalcomitioner fotentiornters at the front inarel.

ECMPUTER PFESFAM; (LLGORITHMS)

This section describes she variaus proufaris that will ar provided to jutumate the Teshicer falctoralvzer pertion of the loborasury. These prograris are written in listc vith a linited number of assembly lunguast patches to take care of such iterrs as da:o logging and timing.

\section{Samit, File Controller}

The samole file controller is described elseahere in this document. This program is to be uses by all instruments, as well os or manayement functions. The operator of the Tecrnicon futaknalyzer would use :his program to creote a morkload listing using the rapurt generator and to edit results (sec Appensices $B$ and $b$ ). The program could bis used to create such reports as. for example, all mercury determinations from a particular creek still in the dat? base.

It will be used to make real-time comparisons of different chemical forms of the same alement. The operazor should be informed immediately if these checks are unreasonable (e.g., ammonia exceeding total Kjeldahl nitrogen). This will be done without the samp!e file controller if necessary.

The sarple file controller takes sample numbers and passes then to the setup program. These numbers can be taken as $c$ block, in oider as found in the mortlaad listing; they can also be reorganized in smaller blocks or individuzlly (see Appendix $E$, .

\section{Setup Program}

The setup progran norkz gn the deta handeg _o í c br zhe samele file_control ler The computer asks wich charnel of the analog-to-digital converter is being used by the analyst. Up to $5 ! x$ different channets can be used with one set of samples. Dilutions of samples, wet weight of secimet!ts. and concentrapion of standards are entered if necssary. The operacor then chcoses a patterr of blanks, qualitycontrol stendard. and samples to use for the run.

Once a standardized pattera has been establishec, it will be storec. It cen be recalied as needed to save repeated manual entir.

The setup progran thet, creates a samplomheel pattern, the standards being interleaved as previously directed by the operator. Since any given $r$ un will ;robably use more than coe filling of the 40position samplet, a printed copy of the pattern will be creazed on the line printer for operator reference. This pattern ausb be thr. same thr uughout the run. An example of the sample-wheel patcern is shown In Appendix D.

There are three different types of quality-control standards: check standards (standards made up by a different oceracor), spikes fo known amsunt of the enalyte 
added to a sample), and duplicates. The operator will enter the concentration of the control standaras. If the computer finds that any of the quality-control standards are outsice the limits, a warning will be placed next to the result on output. When multiple determinations are being run simultaneousty, quality-control information for each analysis should be displayed.

The computer may ask the operator the units of the standards, such as milligrams per liter. After this the operator has an opportunity to change any of the previous data. When he is satisfled, the samplewheel pattern will be printed. More than one pattern can be stored for any one analyte.

\section{Deta Acquisition}

The operatar informs the computer when he has started the run. The first three posizions on the first sample tray must be three standards. These are used by the operator to set the recorder, if desired, and by the computer to measure the time interval. The peak-detection algorithm records the time for the first three standards and the time between peaks ( $Q T$ ). If the time between peeks is not uniform, a buzzer_wlll sourd. The program then reads the next blank, stores it, and looks for the first peak. If none is located in the time expected, the reading taken at the proper time $(T+\Delta T)$ is recorded.

If an off-scale reading is encountered (102 higher than the highest standard), the datum is tagged. The program wili bring this to the operator's attention. If following samples are to.be suspected of_contamination_by_an_off-scale_peak, they will either_ige_tagged_for_repeat_running_or_will_be_corrected_by _a.sEecial 키gorith

\section{Calculations}

The calculations program takes information from the setup program and data acquisition and calculates concentrations and quality-control checks. The values for standards will be transformed into a calibration curve and factors for use in caiculating concentrations.

The concentrations in the samples will be calculated by either using a leastsquares fitting of the srandards data or by interpolation between the two closest stanuards (see Appendix 1). The instrument blank taken before the samples will be used for initial calculations. After a secand blank is taken, the slope of the line between the blanks, or baseline drift, will be calculated. All the samples and standards run between these instrument blanks will be recaiculated, using the interpolated value of the baseline.

As each concentration is calculated, it will be compared to a previous run of the same element in a different state, if applicable. If the results of the comparison are urireasonable, the operator will be notified. Examples might be the ammonia concentration being higher than the total kjeldahl nitrogen or the inorganic phosphorus exceeding the total phosphorus.

If the sample is from a sediment, the program will determine whether percent dry weight is avallable. If it is. results will be reported in milligrams per gram.

The calculations routine will also check the quality-control standards and display 
useful information about each. The control standards will be calculated as if they were samples; the differences between the caiculated values and the concentration as made by the analyst or another person will then be displayed in ásolute values.

The spike samples will be calculated as samples, the previously calculated sample value being subtracted and the absolute recovery of the spike displayed. The absolute difference between the duplicates will be displayed. The limits for the appropriate control chart will be calculated and diselayed. If the standart is on or beyond the warning limit, a buzzer will sound and a message will be displayed.

This routine will also check the data for off-scale values. Any_datum_exceeding ¿_eredetermined_absorbance_range_wil1 be tagged_and_an_apgroximate_value_and_a_suggested_dilution_factor_calculated_and_disglayed. The operator will do the appropriate dilution and put the sample in rhe first open location at the end of the sampler tray. If the concentration of a sample exceeds the calibration range by a fixed amount (usually 10\%), the same action will be taken as with an off-scale sample.

All results will be displayed on the operator's console immedlately after calculation. A_symbol may_indicate which resul ts haye_not_had the intergolated baseline_correction subtracted. When two or more determinations are being run on the same sample, an identifier will be placed in fron: of each result, and all results will be displayed on the same console. The computer can, at predetermined times, give a listing of all samples need- ing dilution. This will be displayed on the terminal.

An addition to the calculation program is an algorithm to correct for the contamination of a dilute sample by a concentrated sample run just previously. This zould be applied to peak heights differing by a factor of 2 or more.

\section{DATA STORAGE REQUIREMENTS}

Approximately 200,000 eight-bit bytes of disk storage will be required to store data during analysis runs in order to operate all 15 channels of the AutoAnalyzers simultaneously. About 200 locations will be required for raw data used by the data acquisition routines for each colorimeter.

\section{COMPUTER OUTPUTS}

\section{Introduction}

One of the computer's most impcrtant tasks is creating useful, timely reports in a variety of formats. Some.of these are described_in_detall in_the section entitled ".Samele File Controller." This section discusses those that are most $\mathrm{im}^{-}$ portant to the TAA operator.

It is important to realize that a timesharing computer system should have a fast enough response for every user to feel that he has the computer to himself. All calculations and reports will be made in near real time.

There will be two different output media. The operator's console will consist of a cathode-ray tube (CRT) or typewriter-style terminal on which alphanumerics will be displayed. There will also be a moderate-speed printer to produce hard copy. it will be shared by all users. 


\section{Work-Load Listings}

The operator can obtain a work-load listing of all of the samples in the data file requiring analysis for any constitwent by the Autohnalyzers, or of all samples requiring analysis for a specified constituent, at any time except when an analysis run is in progress (see Appendices $B$ and $C$ ). The following information will appear on the output:

1. The sample number of each sample.

2. The date thar sample was received.

3. The constituent (s) to be determined for each sample.

4. The Jue date

5. The permit limit, if applicable.

6. Concentration of element in differenc state, if applicable.

\section{Sampler Format Listing}

The sampler format listing is a hardcopy list of the samples, standards, and blanks as they should be loaded into the sample tray. It will be broken into groups of 40 to aid the analyst (see Appendix D).

\section{Standards Calibration Data}

The 5 tandards calibration data will consist of the following:

1. The digital reading as each signal is read.

2. Values of the constants determined for least-squares $f i t$ of the standards data.

3. Statistical parameters for the least-squares fit.

\section{Analysis Progress Report}

The analysis progress report will con- tain the following data:

1. Sample identification number and concentration of samples.

2. Dilution factor and icentification number for diluting off-scale samples.

3. Digital reading of qua?ity-contru! blanks.

4. The concentration found for qua?itycontrol standards and the message."'OK'"-_if they meet_the_test_criteria or a warning buzzer and message if cne is out of limits.

5. For the diluteo samples that were off-scale in the initial run, the following information is given:

a. The dilution factor.

b. The concentration of the original solution.

\section{Analysis Sumfery Report}

A report of a completed run can be generated from the operator's files at the end of each run. An example of a computergenerated report for the operatur's file is shown in Appendix G. The report will contain the following information:

1. Title.

2. Eate.

3. Operator

4. Instrument.

5. Standards source.

6. Units of concentration.

7. Mode of calculation and constants o- statistical data.

8. Sample number.

9. Tit ie of the study.

10. Concentration of the constituent determined.

11. Results of quality-control standards.

12. List of all data used to create control parameters, if requested. 


\section{Signoff}

These system definition and system specifications for the Technicon AutoAnaiyzer, which are not an implementation design, are approved by the undersigned

For Annapolis Field Office: interested parties. It is understood that changes in detail are likely and that the implementation of all features depends on the avallability of funding and maipower.

for LLL:
Analyst

Analyst

Chief, Laboratory Section

Head, Field office
Tean Leader

Project Leader

For Pilot Automation Project: 
Appendix A

Data Flow and Response Times for Sample File Control (SFC.)

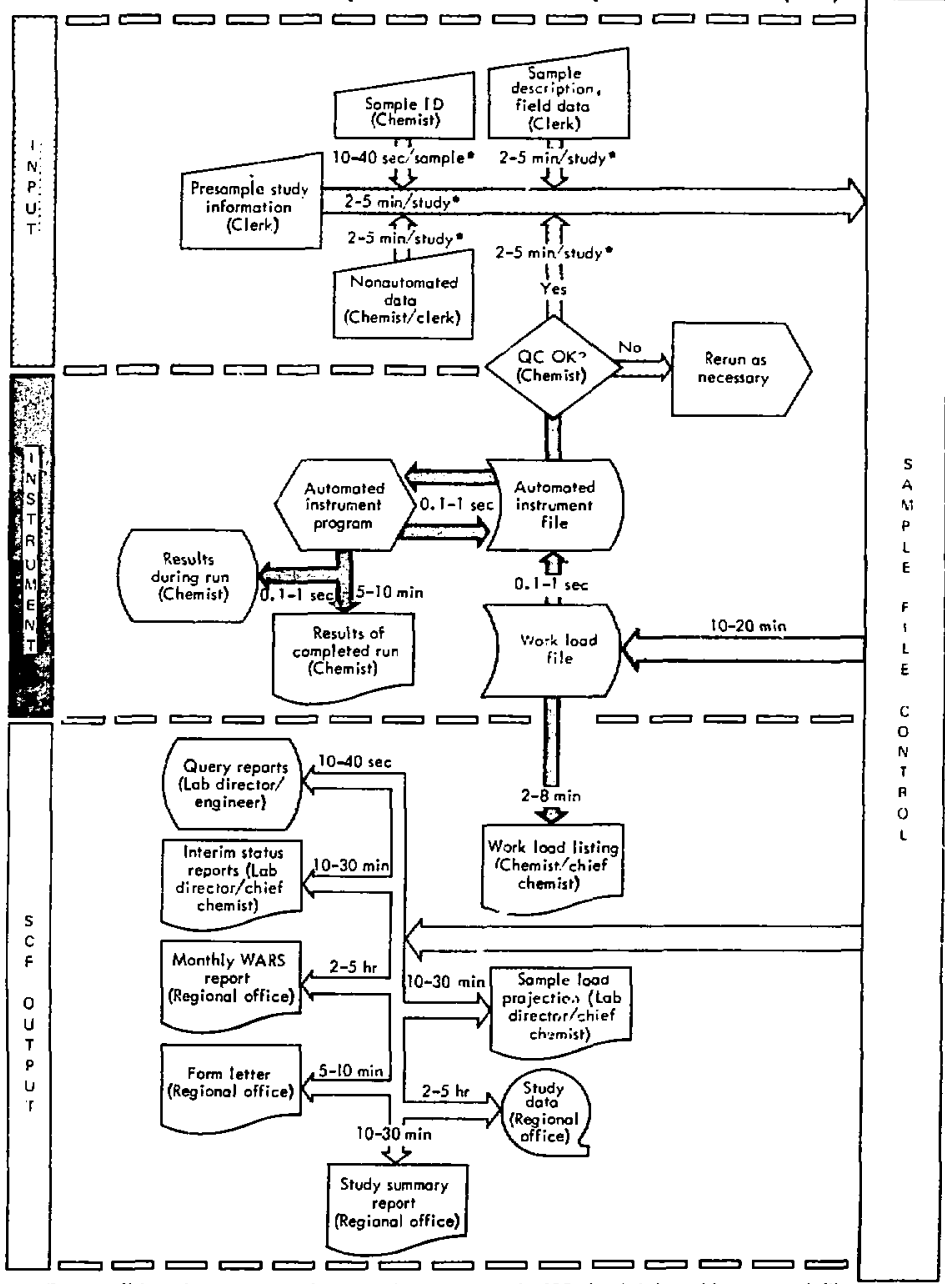

-Time on all input is time required for doto to be written into the SFC ofter it is logged into a scretch file. 
Appendix B

Total Work-Load Listing ${ }^{\dagger}$

LLL BASIC READY
RUN "REPT'"
FORMAT? WORK
STUDY TYPE? WATER
METHOD? TAA
ANALYSIS? ALL
OUTPUT? LINE

[BASIC is read]

[Cal] report generator]

[Work-load I ist format]

STUDY TYPE? WATER

AHALYSIS? ALL

OUTPUT? LINE [Put on line printer]

[A typical output rrom the line printer is as follows:]

SAMPLE

100101

100102

100103

100104

100105

100106

100701

100702

100703
ANALYSIS

\section{TP}

TP

TP

if

TKN

TKN

TP

TP

TKN
DUE DATE

$10 / 3 / 76$

$10 / 3 / 76$

$10 / 3 / 76$

$10 / 3 / 76$

$10 / 3 / 76$

$10 / 3 / 76$

$10 / 9 / 76$

$10 / 9 / 76$

$10 / 9 / 76$

Explanatory coments are given in brackels.

fled part of existing sof twate. 


\section{Appendix C}

\section{Work Lood Listing ${ }^{-t}$}

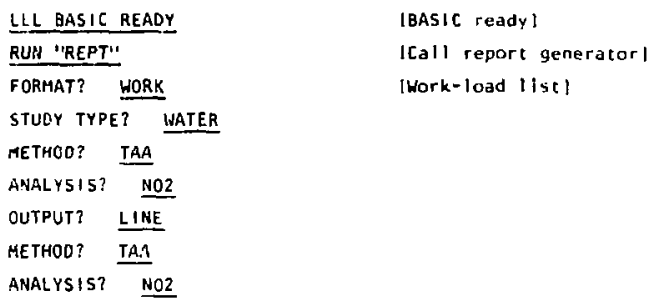

(A typical output from the ine printer is as follows:?

\section{SAMPLE}

110101

110102

110103

120701

120702

120737

120738
RECE IVED

$11 / 01 / 76$

$11 / 01 / 76$

$11 / 01 / 76$

$12 / 07 / 76$

$12 / 07 / 76$

$12 / 07 / 76$

$12 / 07 / 76$
ANALYSIS

$\mathrm{NO2}$

No2

No2

N02

NO2

N02

$\mathrm{NO2}$
DATE DUE

$12 / 10 / 76$

$12 / 10 / 76$

$12 / 10 / 76$

10.0

$12 / 20 / 76$

15.0

\footnotetext{
Exp'anarnry comments are given in brackets. Hot 1 of existing software.
} 
Appendix D

\section{Sample-Wheel Pattern"}

\section{TAA CSM-6}

E. MCPHERSON

$12 / 15 / 1976$

CHAN 6 NO3

CHAN 7 NO2

CHAN 8 NH3

CHAN 9 SILICA

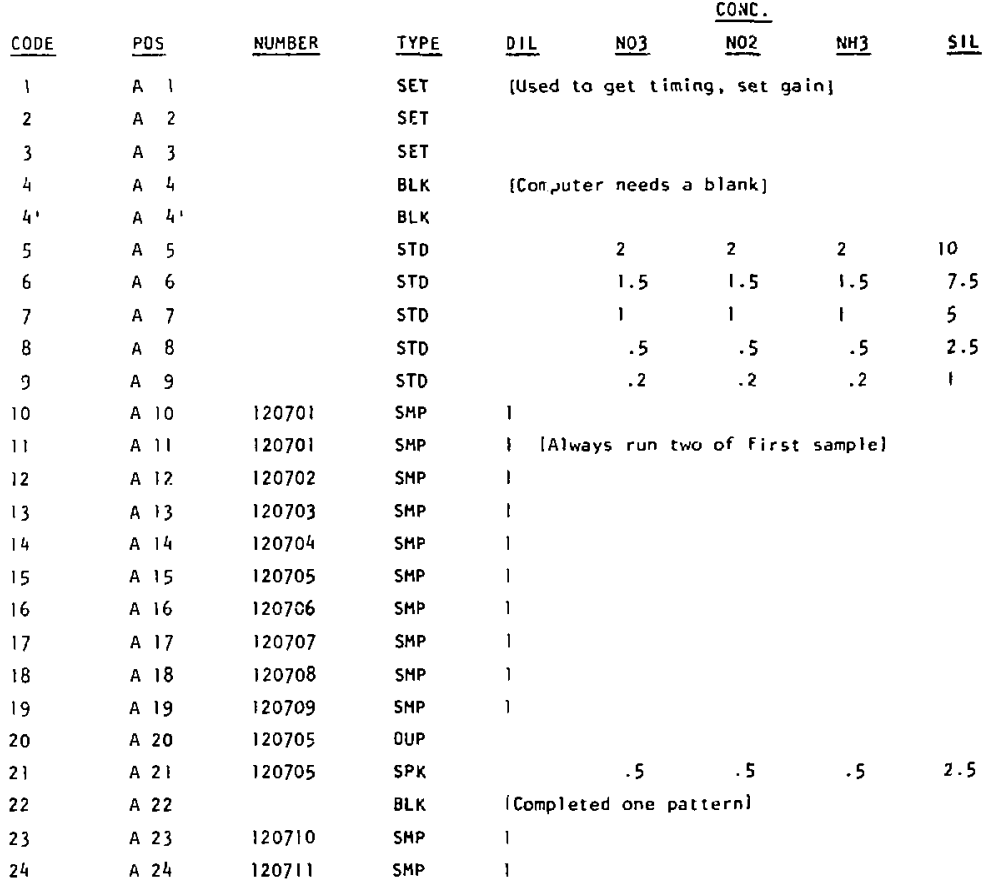

Explanatory comments are given in brackets. 
Sample-Wheel Pattern (continued)

\begin{tabular}{|c|c|c|c|c|c|c|c|c|}
\hline COOE & POS & NUMBER & IYPE & DIL & N03 & NO2 & $\mathrm{NH} 3$ & $\underline{S I L}$ \\
\hline 25 & A 25 & 120712 & SMP & 1 & & & & \\
\hline 26 & A 26 & 120801 & SMP & 10 & & & & \\
\hline \multirow[t]{4}{*}{27} & A 27 & 120802 & SMP & 10 & & & & \\
\hline & - & & . & . & & & & \\
\hline & . & & . & . & & & & \\
\hline & . & & . & . & & & & \\
\hline 40 & A 40 & 120913 & SMP & 1 & I End of first & amole & ier wheel] & \\
\hline 41 & 81 & & SET & & IUsed to estat & ish & & \\
\hline 42 & B 2 & 120914 & SMP & 1 & & & & \\
\hline 43 & B 3 & 120909 & DUP & 1 & & & & \\
\hline 44 & B 4 & 120909 & SPK & & .5 & .5 & .5 & 2.5 \\
\hline 45 & B 5 & & BLK & & & & & \\
\hline
\end{tabular}




\section{Appendix E}

\section{Commands to Transfer Data from the Sample File* $\uparrow$}

\author{
LLL BASIC READY \\ RUN "TAA SEL" \\ REQUESTOR E. MCPHERSON \\ ANALYSIS NO3, NO2, NH3, SILICA \\ SELECT NOS 120701 TO 120712 . \\ 120801 TO 120825 . \\ $120 \underline{900 \quad \text { TO } 120909}$
}

\author{
[Short for TAA select] \\ [Optional] \\ ISelects sets of samples from three \\ different days. Could have selected \\ individual samples or all samoles \\ needing above analyses (ALL)]
}

\footnotetext{
Explanatory comments are given in brackets.

t Not part of existing software.
} 


\section{Appendix $F$}

\section{Example of the Input/Output (1/O) for the Setup. Data Acquisition, and Calculational Programs*}

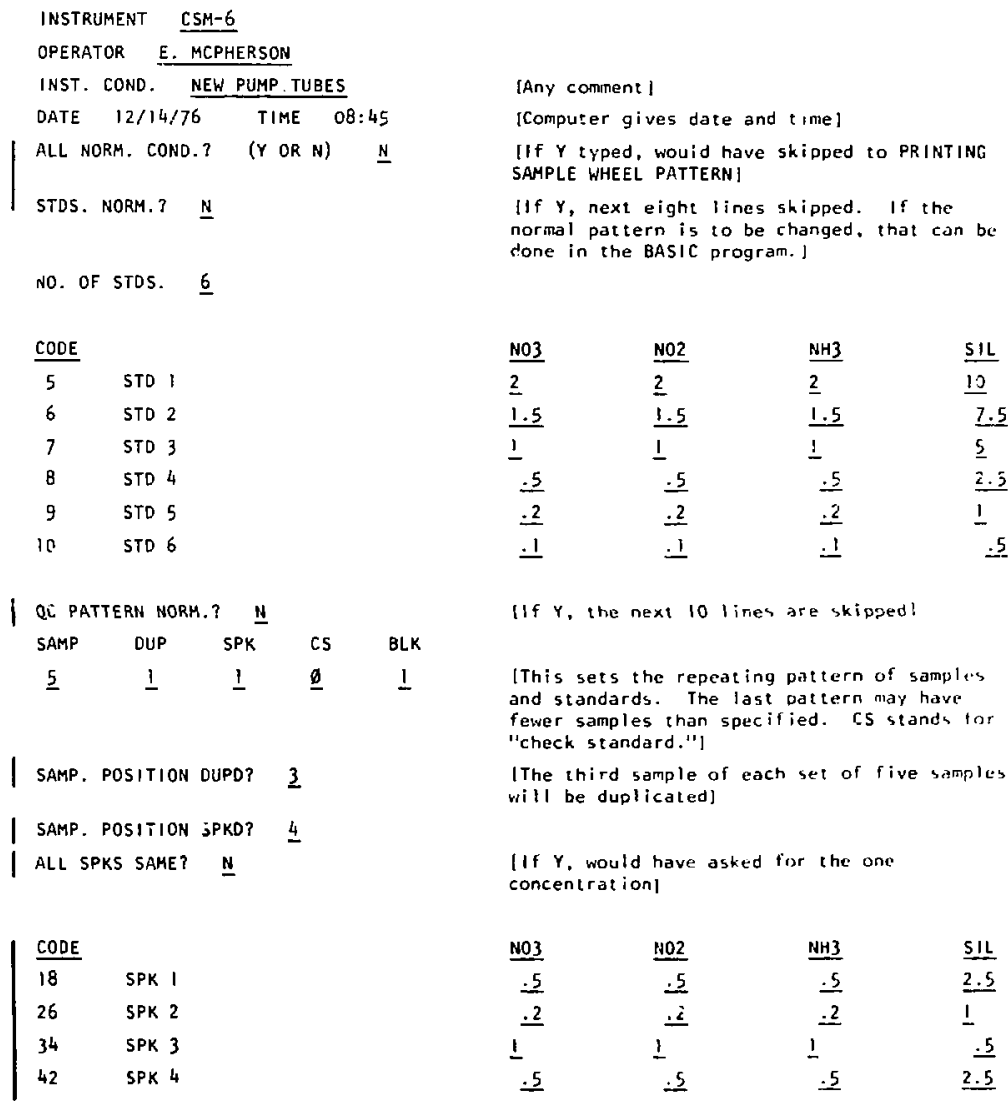

\footnotetext{
"It is assumed that the steps shown in Appendix $E$ have just been completed. Operator's responses are underlined. Explanatory comments are given in brackets.
} 
Example of the Input/cutput $(1 / 0)$ for the Setup, Data Acquisition, and Calculational Programs (continued)

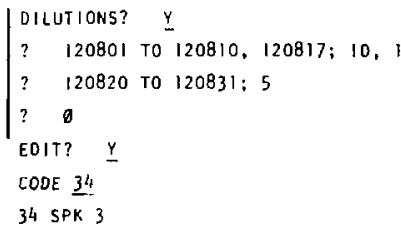

CUDE

PRINTIHC SAMPLE WHEEL PATTERN

EDIT?
HIT RETURN WIHEN READY TO RUN

IIf check siandards had been requested, the conzentration would have been asked for at this point using the same format as spikes! [Are there diluted samples?]

[Bott, tenfold and not diluted]

[Fivefold dilution]

[No more dilutions]

|Chance to corlect mistakes] l

$\underline{1}$
[Change 0.5 to 5 ]

foone editing]

[Another chance after looking at printout]

lTeils computer to start looking for set standards!

N03

A 4 BLAHK 1

$00.10 x$

NO2

NH3

$S ! L$

A 5 BLANK 2

$00.10 \%$

$00.23 \%$

00.173

$00.33 ;$

A 6 CAL STND ।

49.632

$00.22 \%$

00.16 :

00.31 .

A 7 CAL STND 2

$37.42 \%$

$48.77 \%$

49.917

.7 .97 :

$24.8 \%$

$37.39 \div$

37.51 .

$37.32 \%$

12.44\%

$24.96 \%$

25. 02 ,

24.67

A 9 CAL STHD 4

4.88\%

$12.31 ?$

12.55,

$12.29 \%$

A 10 CAL 5TIND 5

$2.42 \%$

4.763

$5.09 \%$

4.63

2.39

2.56 .

2.23 .

LINEAF EQUATIONS

N03 $A / D=+0050.0+8174.0 * \mathrm{C}$, COEFF. OF DETN. $=.99987$

N02 $A / D=-0063.0+8231.0 \div C$, COEFF. OF DETH. $=.99974$

NH3 $A / D=+0009.5+8194.0 \therefore C$, COEFF, OF DETH. $: .99998$

SIL $A / D=-0043.2+1647.0 *$ C, COEFF. OF OETH. $=.99847$

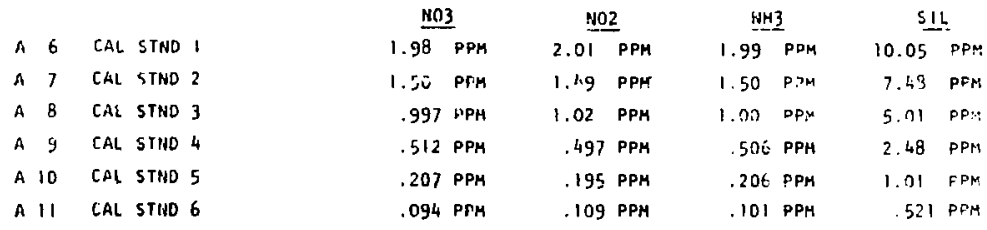

Exibling software con handle only three anolytes. 
Example of the Input/lutput $(t / 0)$ for the Setup, Data Acquisition, and Calculational Programs (continued)

\begin{tabular}{|c|c|c|c|c|c|c|c|c|c|}
\hline & & No & & $\mathrm{NO}$ & & $\mathrm{NH}$ & & SIL & \\
\hline \multirow[t]{3}{*}{ A 12} & 120701 & $13.47 \%$ & & $29.64 \%$ & & $3.42 !$ & & 9.03 & \\
\hline & & .539 & $P P M$ & 1.18 & PPM & -1.37 & PPM & 1.80 & \\
\hline & & \multicolumn{6}{|c|}{ [ Ignore_first_result] } & & \\
\hline \multirow[t]{2}{*}{ A 13} & 123701 & $13.68 \%$ & & $30.51 \%$ & & $3.65 \%$ & & 10.12 & \\
\hline & & .547 & PPM & 1.22 & PPM & .146 & PPM & 2.03 & \\
\hline \multirow[t]{2}{*}{ A 14} & 120702 & $35.62 \%$ & & 64.317 & & $24.19 \%$ & & $21.54 \%$ & \\
\hline & & 1.425 & PPM & 미는 & & .968 & PPM & 4.302 & \\
\hline \multicolumn{2}{|c|}{$\begin{array}{l}\text { DILUIE ANO PLACE IN HEXT } \\
\text { OPEN POSITION }\end{array}$} & \multicolumn{6}{|c|}{$\begin{array}{l}\text { [The sample should be diluted. } \\
\text { sounds to warn operotorl }\end{array}$} & buzzer & \\
\hline \multirow[t]{2}{*}{ A 15} & 120703 & $31.29 \%$ & & $20.51 \%$ & & $1.07 \%$ & & $12.04 \%$ & \\
\hline & & 1.25 & PPM & .820 & PPM & .043 & $\mathrm{PPM}$ & 2.41 & \\
\hline \multirow[t]{2}{*}{ A 16} & 120704 & $40.10 \%$ & & $31.11 \%$ & & $2.53 \%$ & & $20.32 \%$ & \\
\hline & & 1.60 & PPM & 1.24 & PPM & .101 & PPM & 4.09 & PP \\
\hline \multirow[t]{2}{*}{ A 17} & 120705 & $38.21 \%$ & & $26.32 \%$ & & 5.17 & & $36.17^{\prime}$ & \\
\hline & & 1.52 & PPM & 1.05 & $\mathrm{PPH}$ & .207 & PPM & 6.13 & PP \\
\hline \multirow[t]{2}{*}{ A 18} & 120701 & $31.40 \%$ & & $20.63 \%$ & & 1.167 & & $12.23 \%$ & \\
\hline & & 1.25 & PPM & .825 & PPM & .046 & PPM & 2.44 & PP: \\
\hline \multicolumn{2}{|c|}{ DIFFERENCE } & +.004 & PPM + & .005 & PPM + & .003 & PPH + & .036 & $P \boldsymbol{P}$ \\
\hline \multicolumn{2}{|c|}{ I MDUSTEIAL } & $\mathrm{OK}$ & & $\mathrm{OK}$ & & OK & & OK & \\
\hline \multirow[t]{4}{*}{ A 19} & SPIKE I & 52.423 & & 1.73 & PPH & $15.28 \%$ & & $31.51 \%$ & \\
\hline & & $\underline{O F F} \underline{5} C A$ & & 1.73 & PPM & .611 & PPH & 6.31 & PP \\
\hline & RECONERY & $\neq$ & & $98.3 \%$ & & $101.2 \%$ & & $93.2 \%$ & \\
\hline & INDUSTRIAL & $*$ & & OK & & OK & & HARN I NS, & \\
\hline
\end{tabular}

(A buzzer sounds to call operator's attention to the silica spikel
A 20 BLANK 2
$.20 \%$
$.37 \%$
29\%
$.62 \%$

LAt this point the baseline is extrapolated back to the previous one, and each sample or standard is corrected accordingly. Thennew numbers are then_displayed, much like the above. $]$
A 21 120706
21.372
.854 PPM
$15.23 \%$
$11.21 \%$
$20.21 \%$
.609 PPM
$.448 \mathrm{PPM}$
4.05 PPM
B 3 BLANK
$1.01 \%$
$.97 \%$
$.53 \%$
$1.21 \%$

[End of regular run? 
Example of the Input/0utput $(1 / 0)$ for the Setup, Data Acquisition, and Calculational Programs (continued)

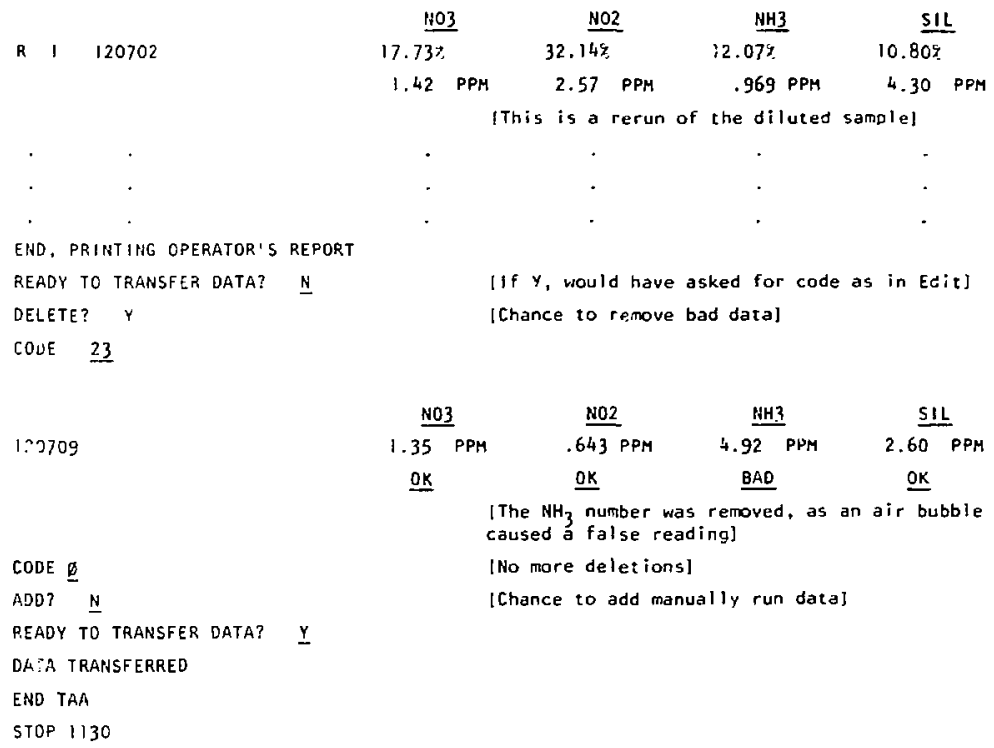


Appendix $\mathbf{G}$

Report for Operotor's Files*

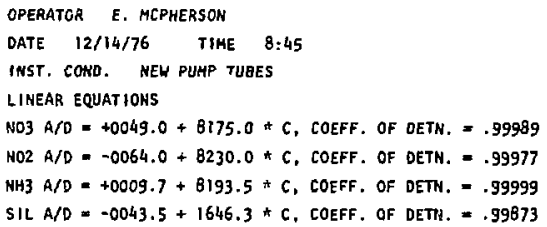

\begin{tabular}{|c|c|c|c|c|c|c|c|c|c|c|c|c|}
\hline \multirow[b]{2}{*}{ CODE } & \multirow[b]{2}{*}{ POS } & \multirow[b]{2}{*}{ MAHE } & \multicolumn{2}{|c|}{$\mathrm{NO3}$} & \multicolumn{2}{|c|}{$\mathrm{NO2}$} & \multicolumn{2}{|c|}{$\mathrm{NH3}$} & \multicolumn{2}{|c|}{ silt } & \multirow[b]{2}{*}{ DIL } & \multirow[b]{2}{*}{ COMH } \\
\hline & & & 焉 & $\underline{\text { PPH }}$ & $\underline{2}$ & PPH & $\underline{q}$ & PPH & 2 & PPH & & \\
\hline \multicolumn{13}{|c|}{ STANDARDS } \\
\hline 5 & A 5 & CAL STD I & 49.60 & 1.98 & 48.71 & 2.01 & 49.89 & 1.99 & 47.92 & 10.0 & & \\
\hline 6 & A 6 & CAL STO 2 & 37.40 & 1.50 & 37.36 & 1.49 & 37.48 & 1.50 & 37.29 & 7.48 & & \\
\hline . & - & $\cdot \quad \cdot$ & • & - & . & - & - & . & • & . & & \\
\hline - & - & - & - & - & . & . & - & - & - & . & & \\
\hline . & . & . $\quad$. & - & - & - & . & - & , & . & . & & \\
\hline \multicolumn{13}{|c|}{ SAMPLES } \\
\hline 11 & $A \|$ & 120701 & 13.47 & .539 & 29.64 & 1.18 & 3.42 & .137 & 9.03 & 1.803 & $\mathbf{l}$ & DK \\
\hline 12 & A 12 & 120701 & 13.68 & .547 & 30.51 & 1.22 & 3.65 & .146 & 10.12 & 2.03 & 1 & OK \\
\hline 13 & A I 3 & 120702 & 35.62 & 1.42 & 64.31 & t & 24.19 & $.96 \mathrm{~B}$ & 21.54 & 4.30 & 1 & RI \\
\hline - & , & . & . & . & . & . & · & - & - & . & - & . \\
\hline - & . & . & 4 & - & . & . & . & - & - & . & - & - \\
\hline - & • & . & • & • & • & • & • & , & • & . & $\cdot$ & - \\
\hline 40 & A 40 & 120813 & 38.21 & 1.52 & 26.32 & 1.05 & 5.17 & -207 & 61.32 & 1.22 & 10 & $O K$ \\
\hline \multirow[t]{2}{*}{44} & R I & 120702 & 17.71 & 1.42 & 32.14 & 2.57 & 12.07 & .969 & 10.80 & 4.30 & 2 & ox \\
\hline & & & & & IT & $\begin{array}{l}\text { aster } \\
\text { on re }\end{array}$ & is is & besid & those & bers $t$ & nat a & \\
\hline
\end{tabular}

SAMPLES THAT HUST DE RERUN

47 ค 4 120805

DIL 1:0*

OFF SCALE

[Must rerun $\mathrm{NO}_{2}$ on this one, first dilution was not

BLAIAKS

$\begin{array}{rllllll}4 & \text { A } 4 & \text { BLANK 1 } & .10 & .23 & .17 & .33 \\ 19 & \text { A } 19 & \text { BLANK 2 } & .20 & .37 & .29 & .62\end{array}$

\footnotetext{
"Tris is an example of the report that is automatically printed at the end of a run. Explanatory comments are given in bracket 5 .

tExisting program can handle only three analytes.
} 
Report for Operator's Files (continued)

CODE POS NAME

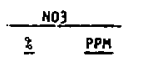

Q C STANDARDS

\begin{tabular}{|c|c|c|}
\hline 17 & $A 17$ & DUP 1 \\
\hline & 120703 & \\
\hline & DIFF. & \\
\hline ' & . & \\
\hline . & . & \\
\hline . & . & \\
\hline 18 & A 18 & SPK 1 \\
\hline & 120704 & \\
\hline & ADOED & \\
\hline
\end{tabular}

$31.40 \quad 1.25$

$31.29 \quad 1.25$

$\frac{\mathrm{NO2}}{\underline{\mathrm{FPH}}}$

$\frac{\text { MH3 }}{1 \quad \text { PPH }}$

$\frac{\text { SIL }}{\underline{\text { PPH }} \text { DIL COMM }}$

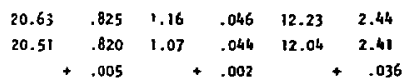

.

$52.42 \Rightarrow$

.

$40.10 \quad 1.60$

$31.11 \quad 1.24$

$15.28 \quad .611$

31.51

6.31

ADOED

$.5=1.74$

$2.53 \quad .101$

20.32

4.09

RECOVERY

4

$.5=.601$

$2.5=6.59$

$97.6 \%$

$102.0 \%$

88.8\%:

.

.

DUPLICATES

INDUSTRIAL WAPHING

..

.

103

-

IndUsta

.031

Nos

.0482

.0352

.0533

..

.

INDUSTAFAL DUT DF CONTROL

.0016

.0030

NH3

.0281

.0422

SIL tThe absolute difference .0642 in concentration between .0964 pared to this number. J

$\begin{array}{lllll}\text { DUP } 1 & .0016 & .0030 & .072 & .0072\end{array}$

\begin{tabular}{|c|c|c|c|c|}
\hline . & - & . & . & . \\
\hline - & - & - & - & - \\
\hline SPIKES & N03 & ho2 & $\mathrm{NH}_{3}$ & 516 \\
\hline INDUSTRIAL WARNING & .0417 & .0521 & .0317 & .0621 \\
\hline I NOUSTRIAL DUT OF CONTROL & .0626 & .0782 & .0476 & .0932 \\
\hline SPIKE & \$ & .0120 & .0100 & $.1116 *$ \\
\hline
\end{tabular}

* $t$ * H MOTE

THERE ARE 25 OR MDRE POINTS IN THE FOLLOHT ING

N03

N02

PLEASE RUN "DৃC UPDATE" 
Appendix $H$

Peak Locator Flow Chart

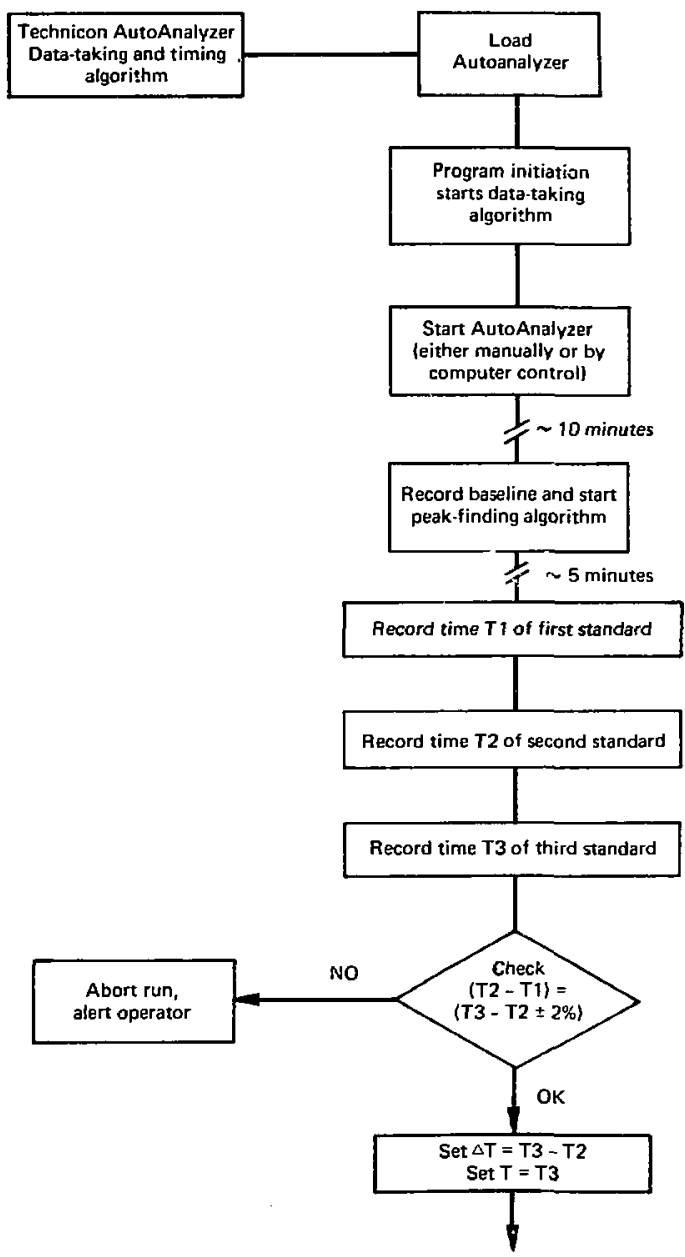




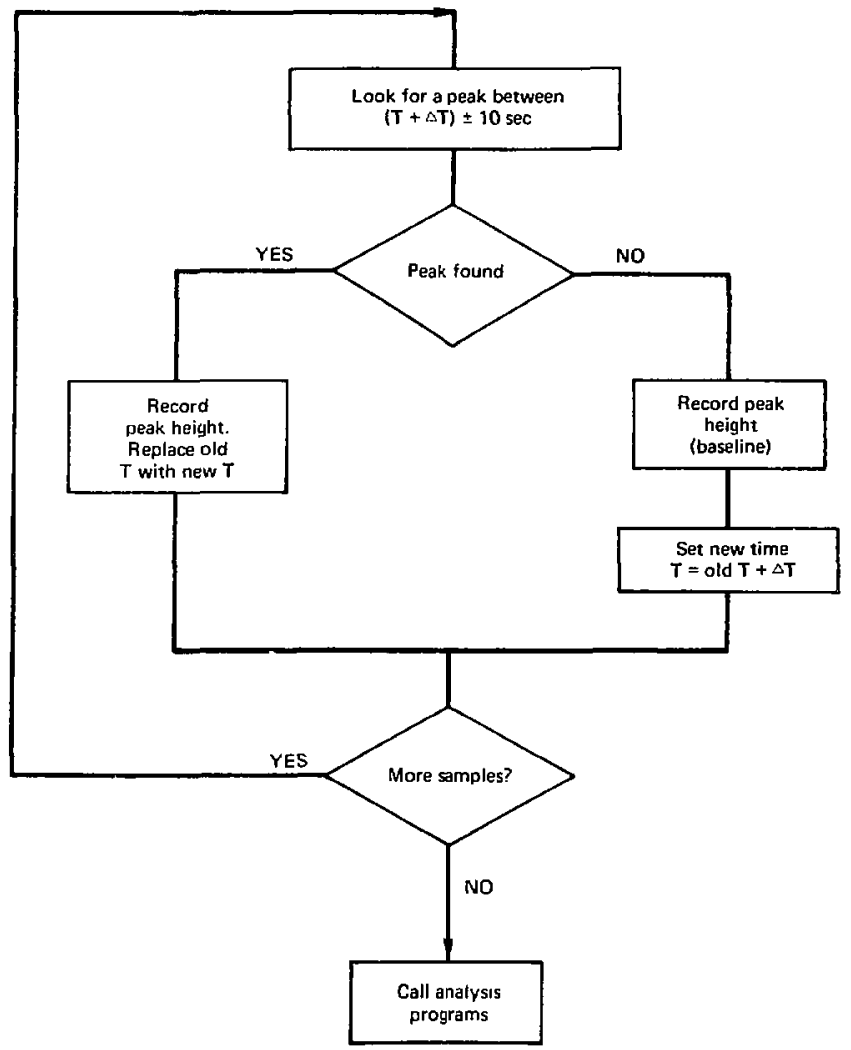




\section{A.ppendix :}

\section{Inlerpolation Definition}

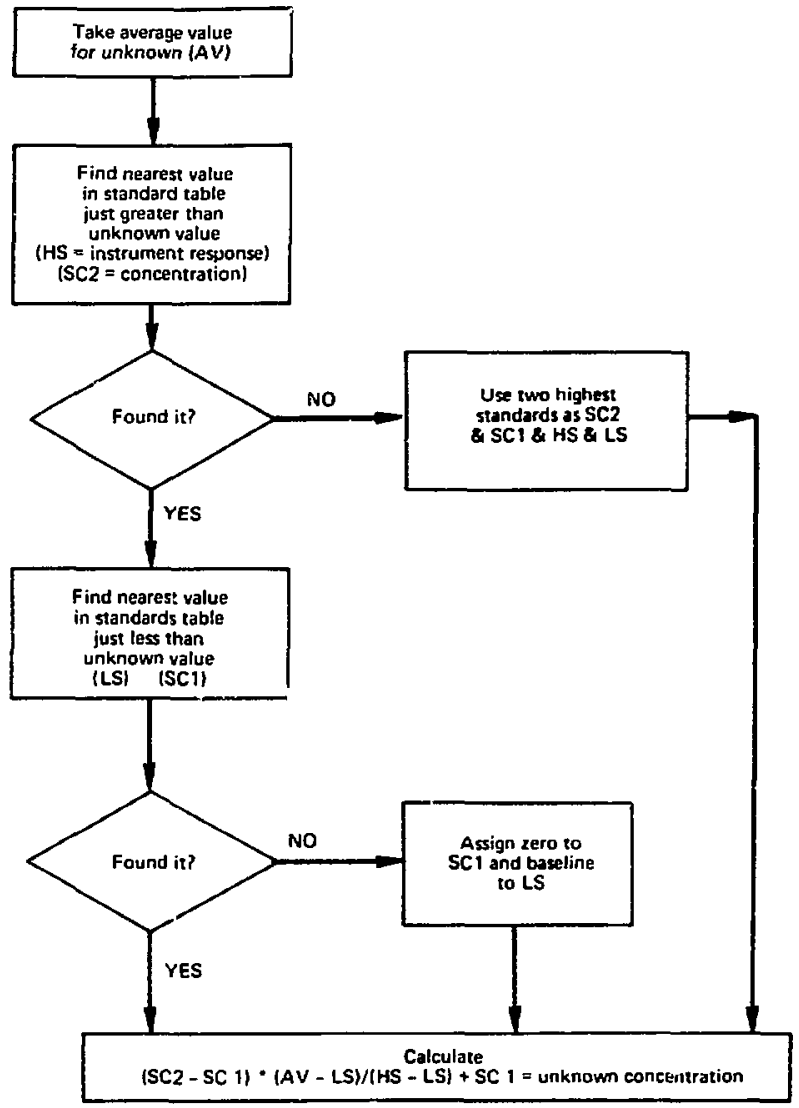


Example of TAA-1 Signal

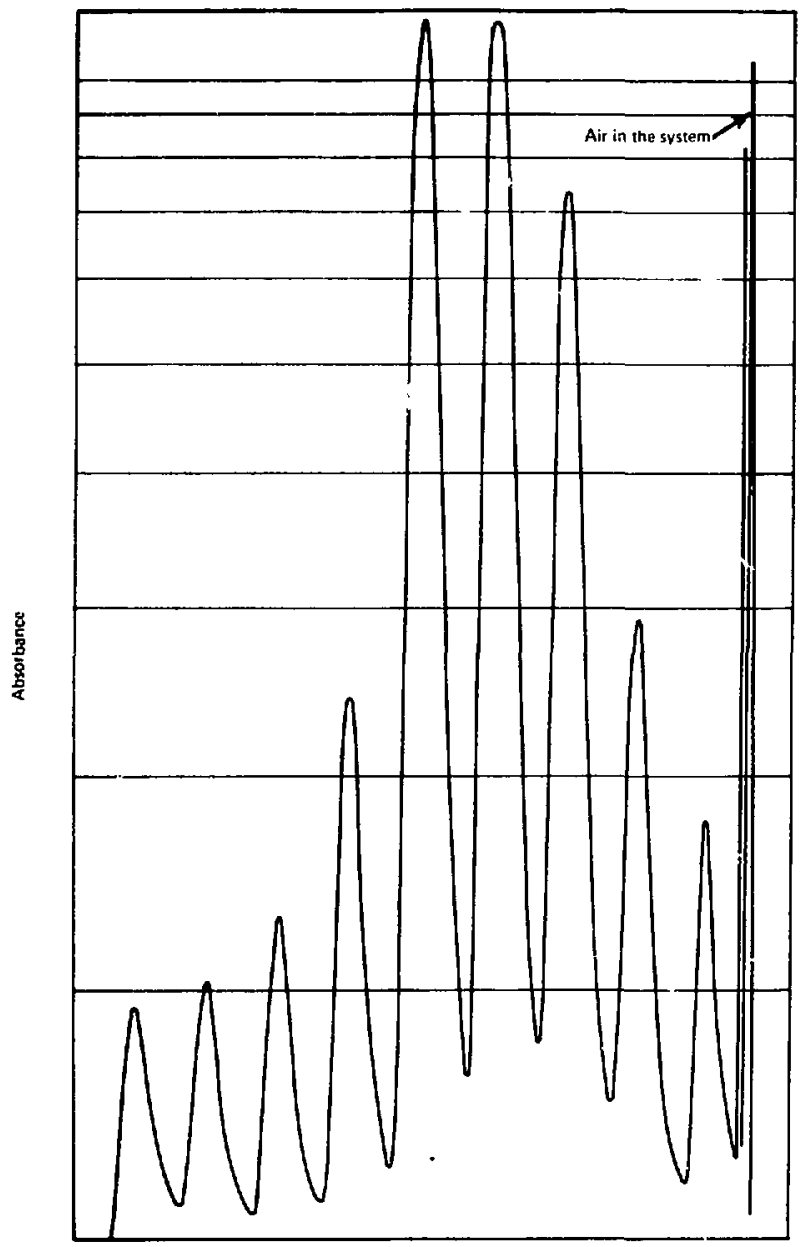


Example of TAA-1 Signar

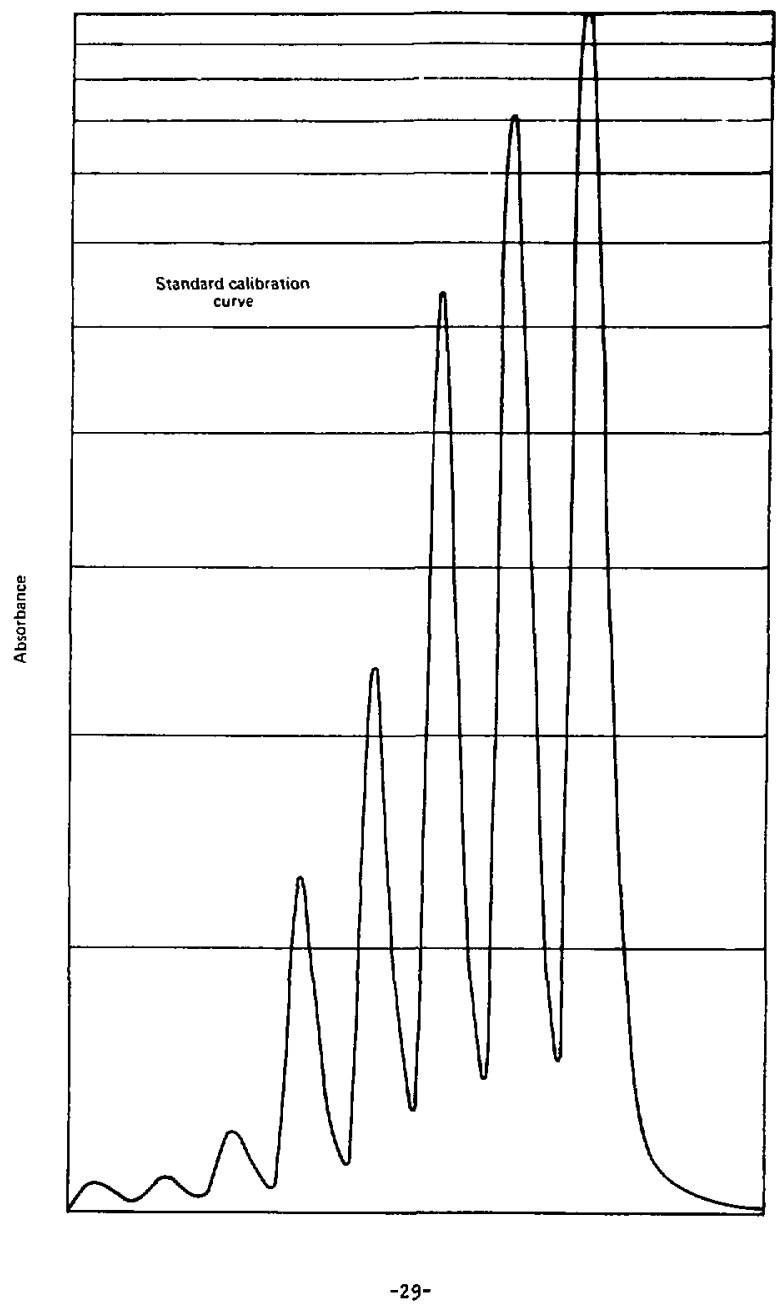


Example of CSH-6 signal

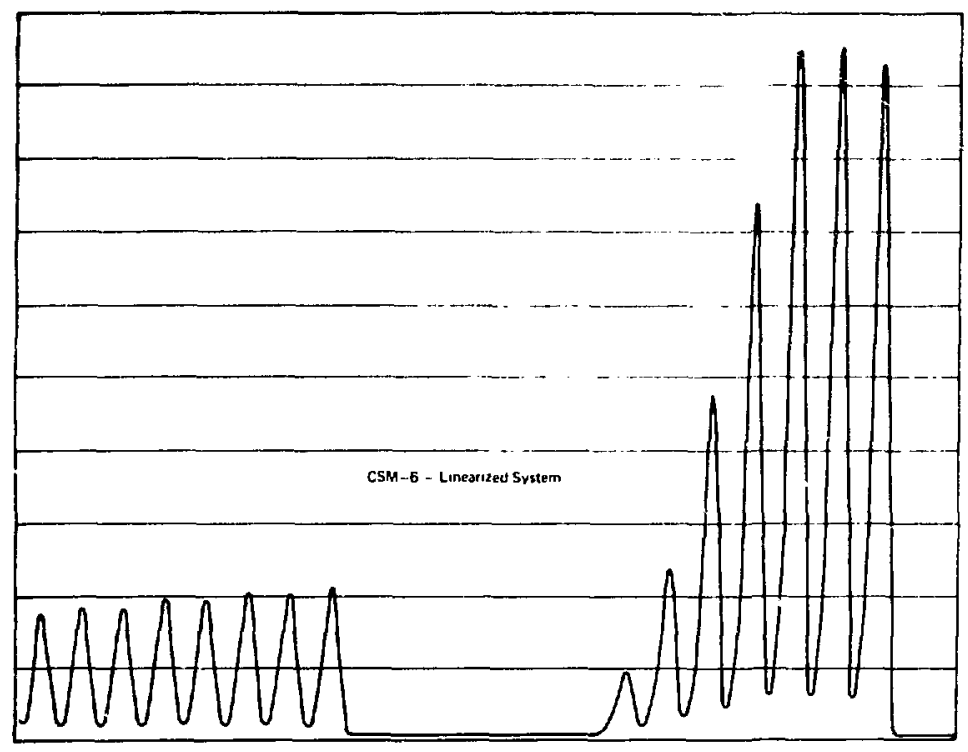




\section{Appendix K}

\section{Timing Flow Chart}
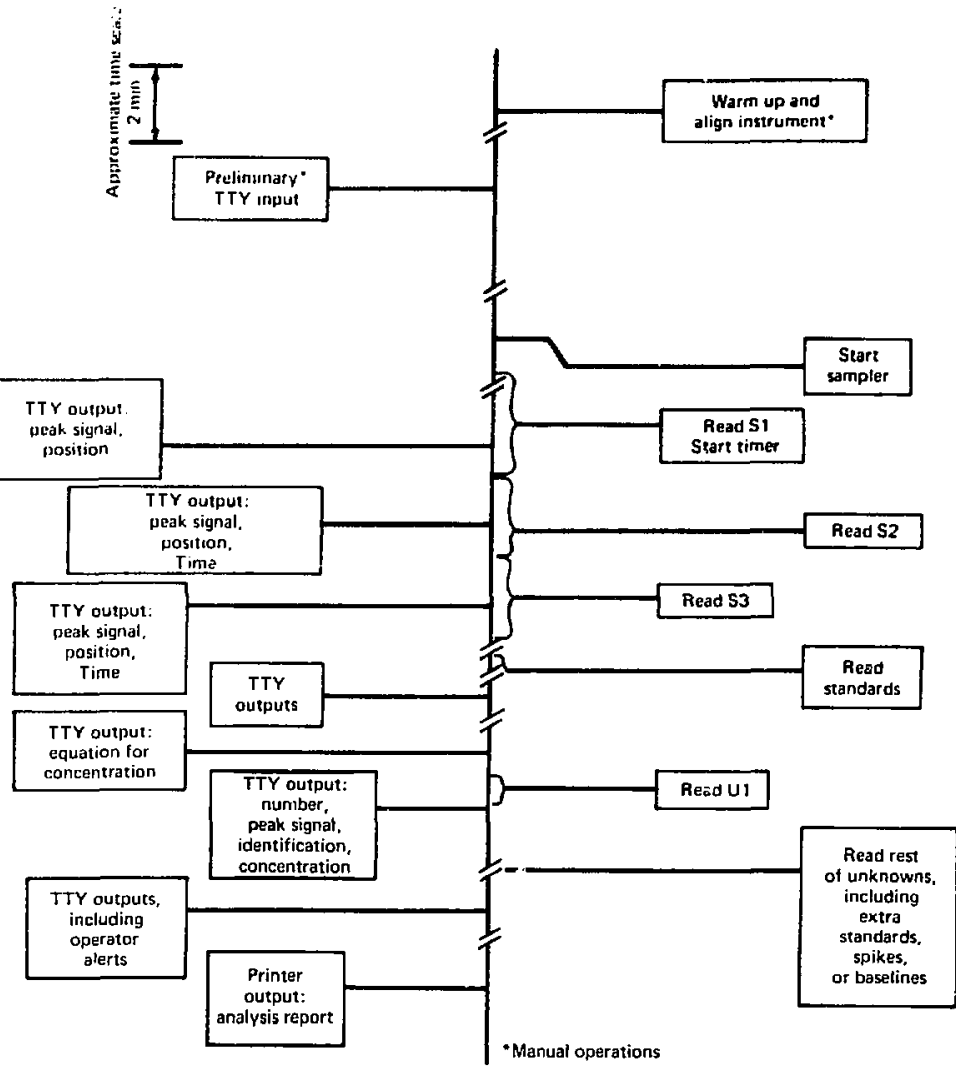


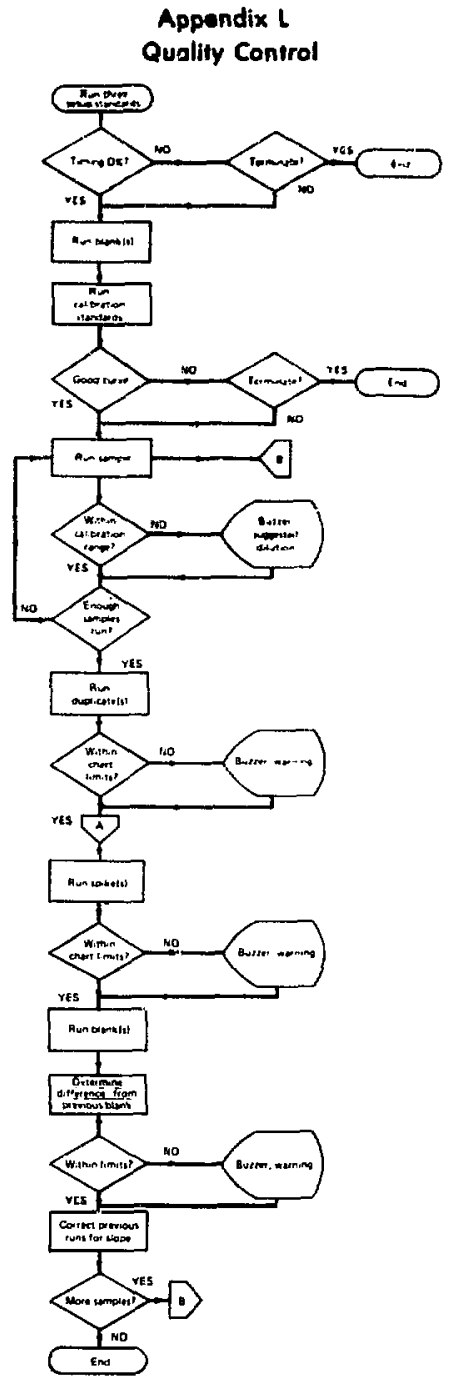




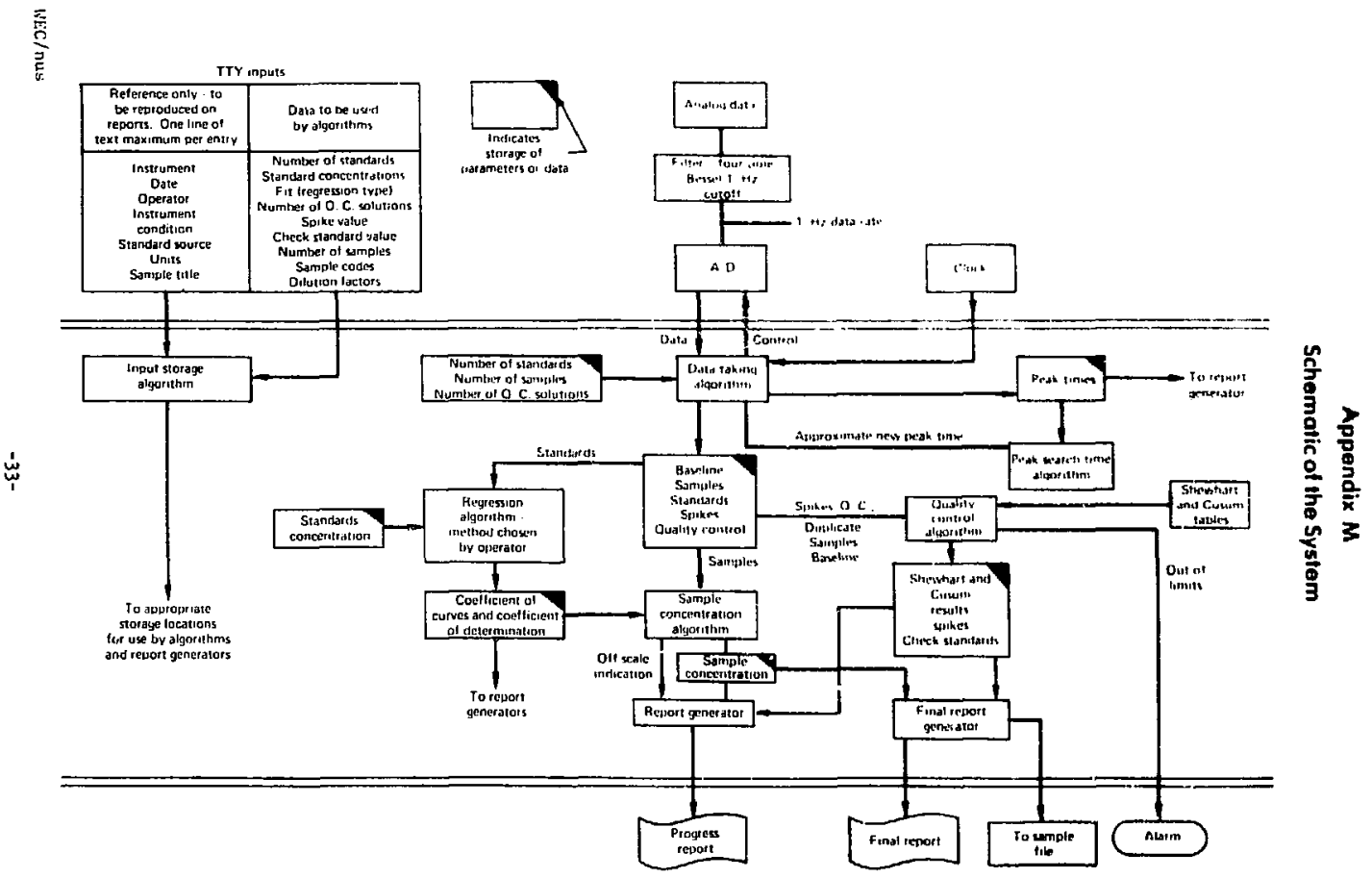

